\title{
The Global Pandemic: A Critical Study on the Impact of COVID-19 on Indian Businesses
}

\author{
Dr. Quazi Md. Kamran \\ Faculty, Dept. of Commerce \& Business Administration, \\ T.M. Bhagalpur University,Bhagalpur \\ Email:kamran.tmbu@gmail.com
}

Abstract

The economy of has been undergoing substantial slowdown over the last few quarters. COVID-19 cases have been rising in the country and the government has taken several steps to flatten the curve, through nationwide lockdown and a complete ban on travel from one stare to another. Central bank's efforts to reduce interest rates and a number of stimulus measures have been taken to bring back the economy on a growth path. Businesses will focus on recovering their outstanding money due from debtors. NPAs, insolvency, and bankruptcies increase multifold.

In this paper the researcher will describe the state of the Indian economy in the pre-COVID-19 period, assess its potential impact across the various sector of the economy, The researcher will also analyze the policies that have been announced so far by the central government and the central bank to improve the economic conditions of India.

Keywords: Economy, Slowdown, Lockdown, Liquidity, Epidemic.

Reference to this paper should be made as follows:

Received: 15.08 .2020

Approved: 28.09.2020

Dr. Quazi Md. Kamran

The Global Pandemic:

A Critical Study on the Impact of COVID-19 on

Indian Businesses

Article No. 20

RJPSS Sept. 2020,

Vol. XLV No. 2, pp. $172-180$

Online available at:

https://anubooks.com/rjpss-

2020-vol-xlv-no-2)

https://doi.org/10.31995/

rjpss.2020.v45i01.020 
RJPSS Sept. 2020 Vol. XLV No.2, ISSN: (P)0258-1701 (e)2454-3403 Impact Factor: 7.717 https://doi.org/10.31995/rjpss.2020.v45i01.019

\subsection{Introduction}

Outbreak of epidemics such as the Spanish Flu and MERS Ebola etc. has been witnessed by the world in the past. India also had to deal with epidemics such as the smallpox, plague, etc. in the past. Covid-19 originated in China and over the next few months spread across the world turned to be the largest health crisis in the world history.

Covid-19 will create similar situations like the Great Depression, 2008 crisis, etc. for the world. The Indian economy was already in a perilous state before the outbreak of Covid-19 but the outbreak of such a pandemic has created an unmatched shock. The country-wide lockdown, the global economic downturn, and the magnitude of the economic impact will depend upon the severity of the health crisis. the duration of the lockdown and the manner in which the situation unfolds once the lockdown is lifted. It is therefore not certain when the lockdown might be lifted or relaxed even in a phased manner, and how long will it take to move towards normalcy. The lockdown period buys time to prepare the health system and to put together a plan of how to deal with the outbreak once the case-load starts accelerating. India's public health system is relatively weaker as the government spends only $1.5 \%$ of the India's GDP on public health. As a result of which India is underprepared to deal with such types of epidemics.

\subsection{INDIAN ECONOMY IN PRE-COVID-19 PERIOD}

As the world is facing demand and supply disruptions and the consequent economic slowdown, therefore, India might be more acute. The economy was in a similar state in the pre-COVID-19 period. The economy had worsened significantly by the time the Covid-19 case was reported in India after years of weak performance. GDP growth slowed to $4.7 \%$ in the year 2019, and unemployment reached a 45 -year high. Moreover, the eight-core sectors Industrial output at the end of 2019 fell by 5.2 which was the worst performance in the last 14 years. On the other hand, investment had been stagnant in the private sector for several years and the consumption expenditure had also been falling. 
Figure 2.1: Statistics related to- Urban demand

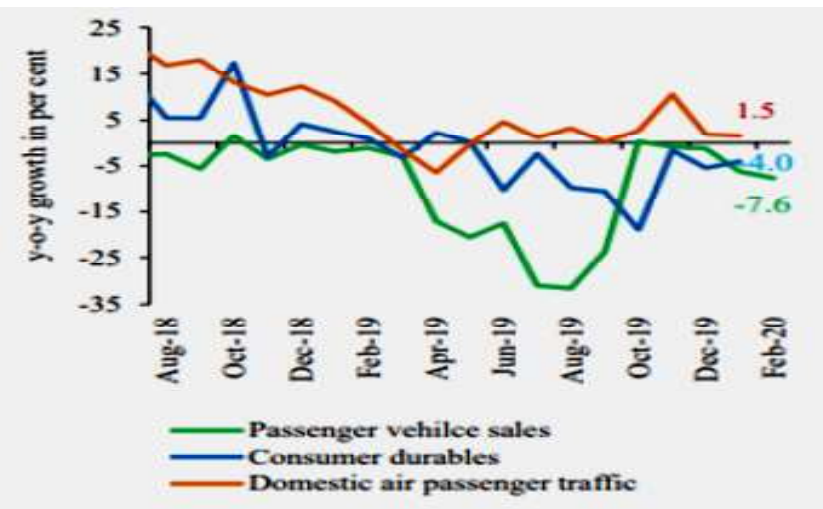

Source: RBI Annual report, 2020

Figure 2.2: Statistics related to- Household credit

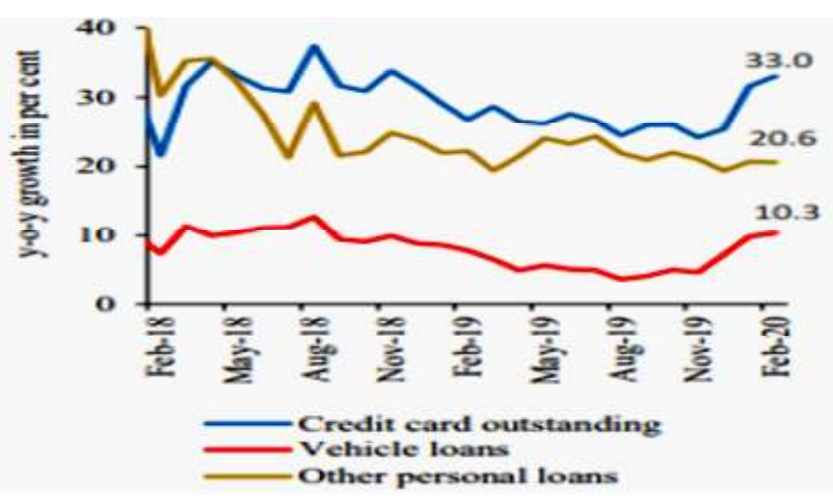

Source: RBI Annual report, 2020

Figure 2.3: Statistics of the Indian banking sector- Credit and deposit growth rate

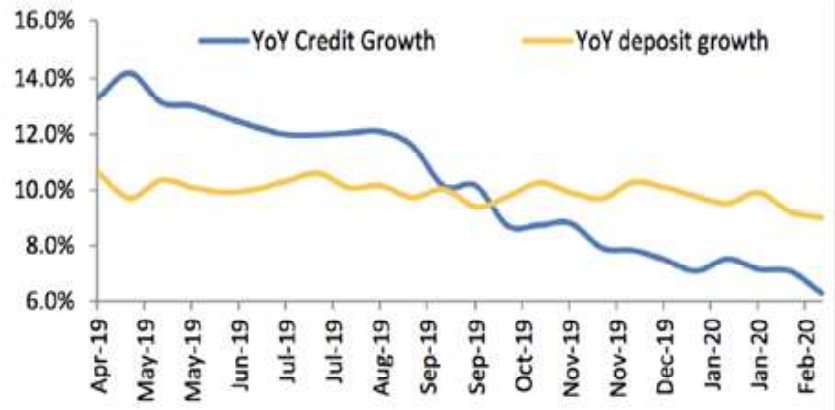

Source: ICRA AmInal repur t, $\angle \mathrm{v}<\mathrm{v}$ 
RJPSS Sept. 2020 Vol. XLV No.2, ISSN: (P)0258-1701 (e)2454-3403 Impact Factor: 7.717 https://doi.org/10.31995/rjpss.2020.v45i01.019

The high-frequency indicators of urban consumption demand highlight that sales of passenger vehicles as well as consumer durables growth contracted in Feb. 2020. On the other hand the indicators of rural consumption, the consumer nondurable sector remained in narrowing in Feb. 2020, indicating feeble rustic demand. Any chance of revival of consumer demand and private investment will dampen due to the nationwide lockdown in the country.

Figure 2.4: Statistics related to Sectoral deployment of credit-Growth rate

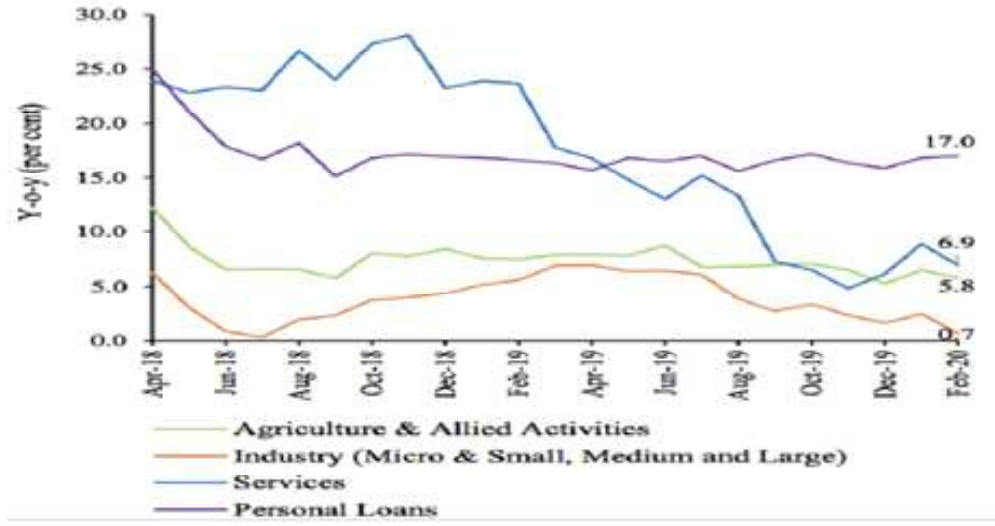

Source: RBI Annual report, 2020

Figure 2.4: Statistics related to Sectoral share in credit flow

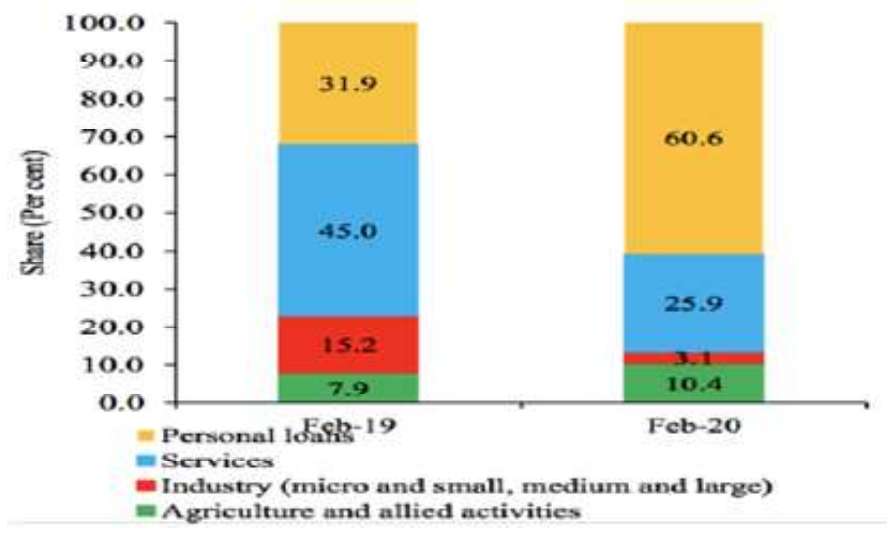

Source: RBI Annual report, 2020

Despite the lowering the repo rate by 135 basis points to $5.15 \%$ in 2019 , credit growth declined sharply which was the lowest rate in the decade. While part of the fall in commercial credit growth may have been 
The Global Pandemic:A Critical Study on the Impact of COVID-19 on Indian Businesses

Dr. Quazi Md. Kamran

Due to lack of demand private sector, evidence suggests that reluctance in banks to extend credit has also been a huge factor. The RBI Governor added that banks have shifted their focus away from industrial loans towards retail loans.

Risk aversion in the banking system has begun hurting the debt markets. As a result of which bank credit growth has been at a multi-decade low. As the short term debt market plays a vital role, banks' holding of non-SLR bonds has declined sharply which means they are averse to credit risk.

\subsection{India's Growth Projections Revised Down}

Currently, the challenges that the businesses and people are facing in India, it is most likely to experience a slower growth in the current fiscal year. Growth may remain subdued in the first quarter of FY 20-21 as well due to the epidemic. Many credit rating agencies have revised India's 2020 and 2021 growth projections.

The Supply chain disruptions, subdued consumption, and investment levels on the growth of the Indian economy are inevitable due to travel restrictions. Covid19 may cost the Indian economy between US\$ 387 million and US\$29.9 billion in personal consumption losses. The projections have been made by ADB under four different scenarios: best-case, moderate-case, worse-case, and a hypothetical worst case.

Under the best-case scenario, the impact on India will be limited to about US\$ US\$ 387 million worth. Likewise, in a modest case, the losses will be about US\$ 640 million whereas in a worst-case scenario personal consumption expenditure in India can decline by US\$ 1.2 billion. India's economic growth forecast has been lowered to $5.2 \%$ for 2020 as against 5.7\% projected by S\&P Global Ratings earlier. The forecast made by, OECD has revised down India's growth forecast by to $5.1 \%$ for 2020-21 and by 5.6\% for 2021-22. Global growth in 2020 as warned by OECD could come down by $50 \mathrm{bps}$ as compared to what was projected in the previous year.

India's economic growth to $4.9 \%$ for $2019-20$ from $5.1 \%$ as projected earlier by Fitch. Fitch expects that the coronavirus outbreak could affect the manufacturing activities adversely. The growth forecast for India has been revised down to 5.3\% for 2020 from $5.4 \%$ as forecasted by Moody's. 
RJPSS Sept. 2020 Vol. XLV No.2, ISSN: (P)0258-1701 (e)2454-3403 Impact Factor: 7.717 https://doi.org/10.31995/rjpss.2020.v45i01.019

\subsection{SECTOR-WISE ANALYSIS OF COVIDE-19 IMPACT IN INDIA}

Given below is the detailed analysis of selected sectors which is going to be impacted due to COVID -19.

\section{Chemical Industry:}

Chemical plants are closed in China, so it is estimated that $20 \%$ of the production will be impacted due to the interruption in raw material supply. Indian Business is likely to get whereas, it is an opportunity for the USA and the European Union.

\section{Electronics Industry:}

India's electronic industry may face supply disruptions as the major supplier in China, and our heavy dependence on electronics component supply directly or indirectly on it.

\section{Automobiles Industry:}

Current levels of inventory seem to be sufficient for the Indian industry whereas, in case of shutdown continues in China then it is expected to result in an 8$10 \%$ reduction of Indian auto manufacturing for the year 2020.

Concerns have been expressed by the Federation of Automobile Dealers Association over the availability of BS-VI vehicles which has made the transition difficult for the sector and hence its outlook is negative.

\section{Agriculture \& Food Processing}

The country employs about 2 crore people who have been impacted as the people are avoiding the consumption of nonveg foods. Wholesale price of chicken had dropped significantly

Agriculture and allied activities sector is already facing losses to the tune of 150-200 crore each day and the prices realized by farmers have crashed. Furthermore, preventive measures should be taken by govt. to avoid the spread of the virus in rural areas.

\section{Pharmaceuticals Industry:}

India imports pharmaceutical ingredients from China. the situation still remaining critical in China so, supply disruptions are likely to continue and amidst uncertainty over future supply, the possibility of a shortage in medicines availability has led to an increase in prices negative pressure on some raw material used in antibiotics has reportedly gone up by about $58 \%$. 
The Global Pandemic:A Critical Study on the Impact of COVID-19 on Indian Businesses

Dr. Quazi Md. Kamran

\section{Mobile Phones:}

Mobile manufacturing companies are also facing a fate similar shortage y of components which in turn increased prices. Companies \& Association estimates suggest manufacturers could see a production impact worth Rs. 6,000 crore due to the epidemic.

MSME:

MSMEs are likely impacted if the lockdown continues and a huge figure of MSMEs face severe cash flow disruption, have an adverse effect on people working in this sector. To ensure the health safety of the MSME workforce, important to ensure that the working capital of such enterprises should be infused appropriately.

\section{Textiles Industry:}

Over US\$ 140 million worth of accessories like buttons, zippers, etc. are imported by the country and such a huge demand can be met by India. Factories were shut down and Indian manufacturers would have to look for local sourcing which may increase the cost and quality may be adversely impacted in such a scenario.

\subsection{KEY MEASURES TO BE TAKEN TO OVERCOME THE SITUATION}

- Maintain liquidity at surplus levels and provide special liquidity support for any companies and financial institutions.

- Support easier credit facilities to effected sections of the businesses

- Disbursement of loans should not be stopped to projects delayed due to COVID19.

- To reschedule payment terms without the need for provisioning by Indian Banks.

- Ask banks to remove the margin of $25 \%$ for a period of 6 months to a year in the DP calculations.

- Moreover, RBI should instruct banks to look at a limited window of the next 6 months for GCP, and the government's capital spending plans despite any shortfall in tax collections should not be avoided.

- Spending on public health is needed to be increased substantially to ensure adequate supplies to deal with COVID-19

- Increase the overdraft facility to different state govt.

- GOI should cut excise duties sharply, and thereby help the revival of demand for the industry.

- People will stand to lose their jobs so the government should give incentives for employers to keep the Relax factory compliances to enable the industry to continue operation. 
RJPSS Sept. 2020 Vol. XLV No.2, ISSN: (P)0258-1701 (e)2454-3403 Impact Factor: 7.717

https://doi.org/10.31995/rjpss.2020.v45i01.019

- Income support should be provided to low-income families through direct money transfer into their account.

- Kisan is already suffering and through higher MSP relief should be provided to them.

- Communication at the district level and joint planning with industry will help to recover at a local level.

- GOI should facilitate ways for safe unloading of shipments and thereby reduce delays at ports.

\subsection{LOOKING INTO THE FUTURE}

Many lives will be lost, countries will introspect, businesses will realign. But now businesses will ensure dependence on China is abridged.

For many businesses things are set to change as technology will now become the frontline requirement. Its importance will be compared to sales and business development functions.

Automation will gain momentum and job creation will be limited. Focus will be on a contractual basis rather than on a full-time job. Working from home will be the new trend and it will also help in saving fixed costs. Businesses will rethink their strategy and focus on profit and profit growth will be the new normal. The conglomerates with large balance sheet exposure will also become history across the globe.

\subsection{CONCLUSION}

An unprecedented challenge for India is the large size of the population. The economy, dependence on informal labor, and social distancing measures would be hugely disruptive. The governments have realized that it is just the beginning. Policymakers should scale up the response and at the same time ensure that a rulesbased framework should be avoided and the exercise of discretion to avoid the damage to the nation.

Covid-19 has paralyzed economies and companies will need to build their financial muscle to stir through the uncertain environment. The nature of the epidemic, is expected to change the business landscape, investments, and consumption patterns so the priority for businesses should be to address the main challenges. Humankind has never learned from history, so it may hope that such a thing is not repeated in the future. 
The Global Pandemic:A Critical Study on the Impact of COVID-19 on Indian Businesses

Dr. Quazi Md. Kamran

\section{REFERENCES}

1. FICCI (March, 2020), Impact of COVID Impact of COVID on the Indian economy. Retrieved from: - http://ficci.in/spdocument/23195/Impact-of-COVID19-on-Indian-Economy-FICCI-2003.pdf.

2. Ishwinder S. Suri (April, 2020), Impact of COVID-19 on Indian Economy and Road Ahead for Corporate Sector. Retrieved: - from:http:// bwdisrupt.businessworld.in/article/Impact-of-COVID-19-on-Indian-Economyand-Road-Ahead-for-Corporate-Sector-/30-04-2020-190322/.

3. Kapur, Dev, Subramanian, and Arvind (2020), "How coronavirus crisis can be converted to the opportunity to fundamentally strengthen Indian economy", Indian Express, April 3, 2020.

4. 4RBI (2020), Monetary Policy Report, Reserve Bank of India, April 2020.

5. S. Mahendra Dev and Rajeswari Sengupta (April, 2020), Covid-19: Impact on the Indian Economy, Indira Gandhi Institute of Development Research, Mumbai.

6. Siddhartha Rastogi(April, 2020), The New Normal: Analysis of COVID-19 Impact on the Indian Economy. Retrieved from: - https://blog.smallcase.com/ the-new-normal-analysis-of-covid-19-on-indian-businesses-sectors-and-theeconomy.

7. Sunil Kumar, Pratibha B Thombare and Pandurang A Kale (April, 2020), Impact of coronavirus (COVID-19) on the Indian economy, AGRICULTURE \& FOOD: e-Newsletter, Volume 2 - Issue 4. 